\title{
Food security and import substitution In the Russian Federation in the post-soviet period
}

\author{
Tatyana Yashkova ${ }^{1,2, *}$, Sergey Kiselev, 2,3 Alexey Opokin ${ }^{4}$, Mikhail Rodionov 2,5. \\ ${ }^{1}$ Academy of Labor and Social Relations, 90 , Lobachevski street, Moscow, 119454, Russia \\ ${ }^{2}$ RANEPA under the President of the Russian Federation, 82, Vernandsky Avenue, Moscow, 119571, Russia \\ ${ }^{3}$ Moscow State Linguistic University, 38 p. 1, Ostozhenka, Moscow, 119034, Russia \\ ${ }^{4}$ State University of Management, 99, Ryazansky avenue, Moscow, 109542, Russia \\ ${ }^{5}$ MSTU GA, 20 Kronshtadtsky Boulevard, Moscow, 125993, Russia
}

\begin{abstract}
The article is devoted to the problem of ensuring the food security of the Russian Federation and the issue of import substitution in the context of increasing geopolitical confrontation, the adoption of sanctions and retaliatory measures, and the deterioration of the economic situation due to the pandemic. The article examines the dynamics of the processes of ensuring the country's food security in the last three decades. The expediency of using the import substitution policy as a tool for ensuring food security is justified. Recommendations are formulated to optimize the processes of import substitution and increase the level of food security. The authors propose comprehensive measures based on current global trends in macroeconomic development and the state of food security in the Russian Federation. Special attention is paid to the expediency of carrying out large-scale work on scientific justification, strategic goal setting and planning, the development of multi-variant scenarios for the development of the situation in the field of food security under the influence of changing factors, with the involvement of a large number of experts and the use of advanced approaches and modern methods.
\end{abstract}

\section{Introduction}

Food security is an important structural element, an integral part, a necessary type of national security of the state. However, the problems of ensuring food security in the Russian Federation that arose several decades ago have not been fully resolved, despite the adoption of relevant regulatory legal acts. According to a number of experts, who the authors of this article agree with, one of the tools for solving the problem is the successful implementation of the import substitution policy, which was initiated in 2012, and subsequently repeatedly corrected due to the sanctions and the difficulties with its practical implementation.

The authors used a set of methods: content analysis, which made it possible to study the provisions of regulatory legal documents, such as the Federal Law "On Food Security of the Russian Federation", the Food Security Doctrine of the Russian Federation of 2010, the Food Security Doctrine of the Russian Federation of 2021, the Action Plan ("road map") for the implementation of the provisions of the Food Security Doctrine of June 9, 2020 (as amended on March 18, 2021); event analysis, which allowed to study the development of the situation with the solution of the food security problem in the period from 1992 to the present the time; the system method; the method of comparative analysis; the method of expert assessments.

\section{Research results and discussion}

The post-reform years of the 1990s led to a state of Russian dependence on a number of foreign goods and groups of goods, including agricultural products, which affected the level of national security, in particular, in the food sector. During this period, the Russian Federation, actually, de-facto lost food security, which in the USSR was provided for almost all major types of agricultural products (with the exception, perhaps, of fruits and some vegetables). By the way, as follows from the information of the Federal Customs Service and Rosstat (Federal state statistics service), Russia is still seriously dependent on fruit imports.

The debate over "food security" in the Russian Federation over the past ten years has really been a debate over agricultural policy. More specifically, it concerns how to interpret the changes in agricultural production and consumption that have accompanied the introduction of reforms in the economy. There have been two quite important changes in production in the country since policy reforms started in 1992: a sizeable fall in livestock inventories and a corresponding fall in production of feed grain. Accompanying these changes has been a sizeable fall in grain imports and an increase in meat imports. On one side, the agricultural establishment has interpreted these changes as an ongoing "crisis" in the agricultural sector that threatens the food security of the country. 
The Russian Parliament, concerned about this, in 1996 adressed the draft federal law No. 967000526-2 "On Food security of the Russian Federation", the main requirement of which was to provide the population with food products made by domestic producers. After lengthy discussions, on December 10, 1997, the Federal Law "On Food Security of the Russian Federation" was adopted, which states that "food independence of Russia is considered unsecured if the annual production of vital food products is less than $80 \%$ of the annual consumption of the population in these products in accordance with the physiological norms of nutrition". However, the food security situation continued to deteriorate. Let's, for example, look at one of the indicative parameters - in 2000 , with the total production of poultry meat of 0.77 million tons, the amount of import reached almost 90 percent ( 0.69 million tons), and two years later the amount of import increased to 150 percent, since in 20021.34 million tons of poultry meat were imported.

In 2010, the leaders of the state decided to take measures aimed at stopping the decline in the level of food security, for which a document was adopted under the name of the Food Security Document of the Russian Federation. Food independence thresholds were set for a number of products.

A very serious circumstance should be noted, which to some extent explains the existing difficulties, and lies in the fact that it is not so easy to protect the national economy and domestic producers from unfair competition from foreign goods by a well-known method of conducting a protectionist customs policy at the present time. Here is a classic example. At the end of the XIX century, the Russian Empire fell into trade and commodity dependence on European countries, primarily Germany. The famous economist D. I. Mendeleev (who called himself a political economist first and then a chemist) developed a major work called "Tolkovy tariff" (competent rate). This work was so successful that it formed the basis for the state customs tariff adopted in 1891. As a result, thanks to a reasonable customs and tariff policy, Russia began to develop rapidly in economic terms-and not only in agriculture, but also in industry, and came out on top in the world in terms of economic growth, infrastructure development (railway network), demographic growth, etc. [5]. However, at the present time, the implementation of a protectionist customs policy is limited by the conditions of Russia's accession to the World Customs Organization, according to which the introduction of higher tariffs on imported products (cannot be set above $25 \%$, and in some cases even less) is prohibited, not to mention the introduction of protective customs tariffs. True, there are still non-tariff customs measures, such as phytosanitary control measures, but their application does not lead to a drastic solution to the problem. In such conditions of customs and tariff regulation, as well as the large-scale entry of foreign agricultural products into the liberalized Russian market, often subsidized, creating unfair competition, domestic food production turned out to be almost uncompetitive.
In the current situation, the decision to form and implement a policy of import substitution as a tool for ensuring food security is quite reasonable. Fortunately, the country has the necessary land, water and human resources.

The beginning of the formation and implementation of the import substitution policy can be attributed to 2012-2013. In the State Program for the Development of Agriculture for 2013-2020, among other goals, import substitution was identified. In August 2015, the Government Commission on Import Substitution was established. In the future, a set of various measures in this area was carried out. For example, in 2018, the Ministry of Agriculture increased the number of subsidies for farmers and family farms.

In general, a lot of work has been done. And it must be said that the implementation of the import substitution policy has undoubtedly had a certain impact on the state and efficiency of the functioning of the domestic agricultural complex, but not only positive. On the one hand, import dependence has decreased - in 2019, agricultural imports amounted to $82 \%$ of the level of 2010, the share of imports decreased in almost all product groups, although it remains quite high in several of them. On the other hand, the issue of increasing the competitiveness of goods, food safety parameters (this indicator in Russia is significantly lower than in developed countries), economic accessibility (decreased) and the quality of goods for the population, with a harmonious balance of large agricultural holdings and farms, and the interaction of farms with end points of sale has not been resolved. The unsolved problems did not allow us to ensure a sufficient level of food security in the country.

The urgency of the problem of food security in the conditions of increasing geopolitical confrontation and the presence of objective difficulties in ensuring it dictated the adoption in early 2020 of the new Doctrine of Food Security of the Russian Federation (approved by Decree of the President of the Russian Federation of 30.01.2020 No. 20), which is "a set of official views on the goals and main directions of state economic policy in the field of ensuring food security of the Russian Federation". It is appropriate to note that the draft of this document was adressed in March 2019 at a meeting of the Interdepartmental Commission on Security in the Economic and Social Spheres established in the Security Council of the Russian Federation, which was attended by members of the Scientific Council of the Security Council of the Russian Federation and experts. At this meeting, the reason for the creation of a new version of the Doctrine was explained - the change in the socioeconomic situation, new risks, primarily related to sanctions [9], the expansion of the openness of the domestic market, and the creation of a single customs space within the EAEU [10].

The doctrine provides for a change in the previously adopted methodology for calculating food security. To assess it, instead of the share of domestic production in total domestic consumption, an international indicator of self-sufficiency will be used. It includes the ratio of production to consumption and the compliance of 
products with the requirements of the EAEU regulation. The Doctrine itself states that "the need to approve a new Doctrine is dictated by the significantly changed conditions of the country's socio-economic development in recent years, the emergence of new risks and threats to food security caused mainly by economic sanctions imposed by a number of Western countries against Russia, the increased openness of the national agricultural market associated with joining the World Trade Organization, and the deepening of integration processes within the EAEU" [2].

It is important to note a fundamental point - in the new edition of the Document on Food Security of the Russian Federation, clear parameters of its own mandatory production of agricultural products are specified: grain - not less than $95 \%$; potatoes - not less than $95 \%$; milk and dairy products - not less than $90 \%$; meat and meat products - not less than $85 \%$; vegetable oil - not less than $85 \%$; salt - not less than $85 \%$; sugar not less than $80 \%$; fish products - not less than $80 \%$. The threshold values of food independence for a number of products, for example, fish, sugar, were increased by 5 10 points. And although a certain part of the parameters specified in the Doctrine (for example, for wheat, vegetable oil, fish products) has reached the set values, the work is considerable.

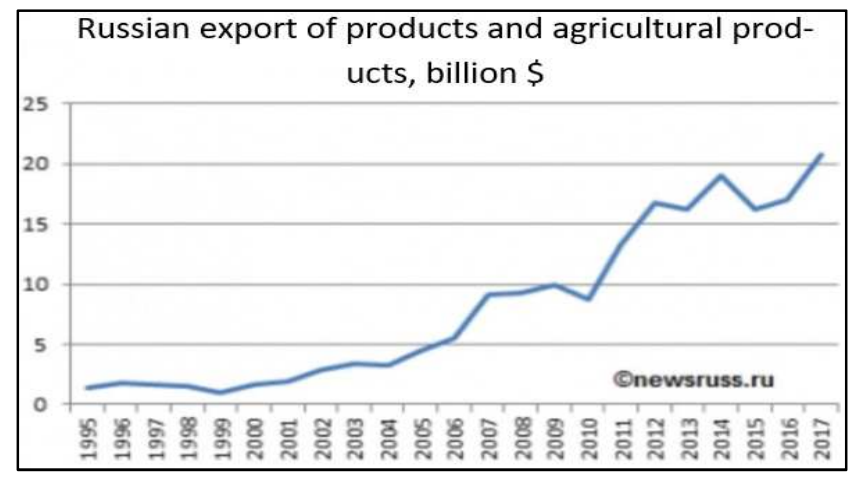

Fig. 1. Russian export of products and agricultural products over the last 25 years, billion dollars

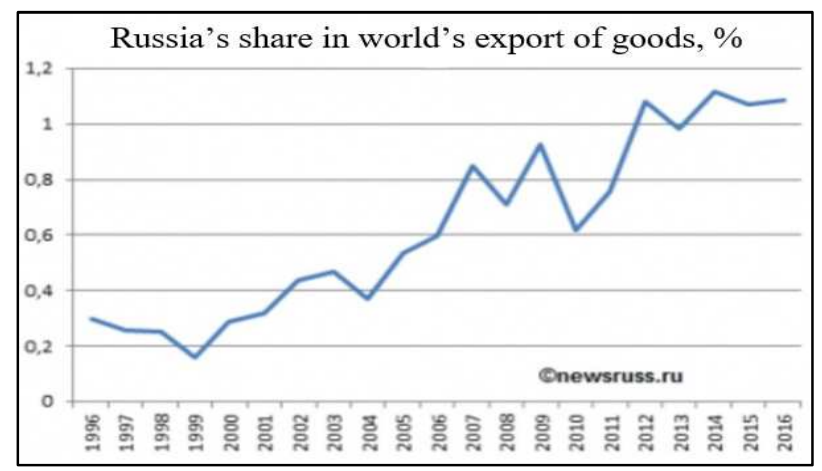

Fig. 2. Russian share in world's export of goods over the last 25 years, percentage

Another important step is the adoption by the Government of the Russian Federation of the Action Plan ("road map") for the implementation of the provisions of the Food Security Doctrine (Order No. 1516-r of June 9, 2020), which specifies the terms, responsibilities and monitoring of implementation, including the annual (no later than April 15) submission to the Government of the Russian Federation of a draft report to the President of the Russian Federation on the state of food security. Responsible executors are the Ministry of Agriculture of Russia, the Ministry of Economic Development, the Ministry of Health, the Federal Customs Service, the Ministry of Finance, the Ministry of Industry and Trade, Rospotrebnadzor (Federal Service for Surveillance on Consumer Rights Protection and Human Welfare), Rosstat, and the Federal Security Service of Russia.

According to the Action Plan for the implementation of the provisions of the Food Security Doctrine, Rospotrebnadzor, the Ministry of Agriculture and the Russian Agriculture Ministry are responsible for monitoring the compliance of food products with the mandatory requirements of the technical regulations of the EAEU, with the provision of an annual report to the Government of the Russian Federation. The Ministry of Agriculture implements measures aimed at the development of rural areas within the framework of the state program of the Russian Federation "Integrated development of rural Areas", takng into account the provisions of the Food Security Doctrine of the Russian Federation (with the provision of an annual report to the Government of the Russian Federation). The Ministry of Health, the Ministry of Economic Development, the Ministry of Agriculture and Rospotrebnadzor have been instructed to implement the basics of state policy in the field of healthy nutrition of the population. The Russian Academy of Sciences is responsible for the theoretical justification in this area of activity. Control over modified organisms used for the production of food raw materials and food products, as well as food raw materials and food products obtained with the use of modified organisms or containing such organisms is entrusted to the Rospotrebsoyuz (with the provision of an annual report to the Government of the Russian Federation). Another important area is the development of a methodology for calculating the level of self sufficiency in agricultural products, raw materials and food, and its consolidation in the regulatory legal act of the federal executive body, entrusted to Rosstat and the Ministry of Agriculture of Russia.

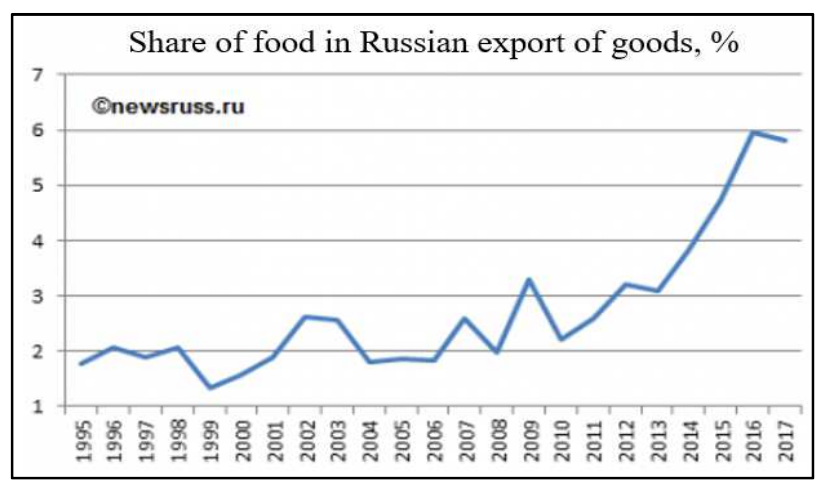

Fig. 3. Share of food in Russian export of goods over the last 25 years, percentage 
On March 18, 2021, adjustments were made to the Action Plan, taking into account the economic situation. In particular, the Action Plan for the implementation of the provisions of the Food Security Doctrine was supplemented by another area of work, which is to ensure an increase in the level of self-sufficiency of the country with seeds of the main agricultural crops of domestic selection. All this shows the seriousness of the Russian leaders' intentions to ensure food security.

\section{Conclusion}

The analysis of the state of food security in the Russian Federation, taking into account the functioning of the import substitution policy as a tool for ensuring food security, allows us to make some conclusions and formulate certain recommendations:

1. The main global trends of macroeconomic development in the context of geopolitical confrontation and pandemic are: a) the food security of countries with a noticeable increase in protective measures aimed at protecting national producers; b) the increasing importance of sufficient and high-quality food, taking into account its impact on human immune protection.

2. The problem of ensuring food security in the Russian Federation is still quite acute.

3. The implementation of the import substitution policy is considered, along with the customs and tariff policy, the main tool for ensuring a sufficient level of food security.

4. Given that the expectations of the sanctions situation, as a determining factor in the activation of domestic agricultural production, have not been fully met, there is a need for more active involvement of state regulators (tax, customs, investment, preferential, statelegal, administrative and managerial, and others), which are primarily aimed at organizing the production of agricultural products with high added value, high-tech and competitive in the domestic and global markets, manufactured on the basis of high-performance resourcesaving innovative technologies.

5. It is advisable to carry out large-scale work on scientific justification, strategic goal-setting and planning, development of multi-variant scenarios of the development of the situation under the influence of changing factors-with the involvement of a large number of experts (hundreds or more), as well as using advanced approaches and modern methods. In particular, the foresight methodology, which allows you to evaluate and predict the strategic vectors of socio-economic and innovative development. An example from world practice - in Japan, about 2 thousand experts are involved in the development of strategic projects for scientific and technological development, carried out every 5 years, and about 10 thousand experts from various fields of science and technology took part in a recent similar project in South Korea. Such an approach can provide a breakthrough-solving the problem of scientific justification of ways to ensure food safety.

6. In the conditions of increasing turbulence of the geopolitical situation, in the process of ensuring food security and import substitution, it is advisable to use approaches based on preventive anti-crisis management, using risk management and information security approaches based on the use of new information technologies and artificial intelligence methods tested in other sectors of the national economy [6].

7. The situation dictates the usefulness and necessity of expanding and intensifying scientific and information platforms (strategic sessions, conferences, symposia, round tables, expert councils) to discuss problems and search for vectors and tools for solving issues of import substitution and ensuring food security. We note the Strategic Session "Russian Agroexport 2020-2021", held by the Federal Center "Agroexport" on December 16, 2020. Another worthy example is the one held in Kursk on May 12, 2021. International scientific and practical conference "The role of agricultural science in the sustainable development of the agro-industrial complex", dedicated to the 70th anniversary of the Kursk State Agricultural Academy named after I. I. Ivanov, and which considered a wide range of problematic issues that allowed us to formulate valuable recommendations of scientific and practical plans

\section{References}

1. Decree of the President of the Russian Federation No. 208 The strategy of economic security of the Russian Federation for the period up to 2030 (2017)

2. Presidential Decree No. 20 The Doctrine of Food Security of the Russian Federation (2020)

3. V. V. Vorob'eva, S.P. Vorob'ev, O. Titova Bulletin of the Altai Academy of Economics and Law 9 (1), 31-36, (2020).

4. P. I. Ivanov Proceedings of the Academy of Management of the Ministry of Internal Affairs of Russia. April-June 2020. 2, 131-141.

5. S. G. Kiselev, M. M. Savchenko History of customs affairs and customs policy of Russia (VIbeginning of XX centuries): A course of lectures. (Moscow: Russian Customs Academy, 2016)

6. M. A. Rodionov Financial Risk Management. Moscow, 2 (62), 120-128 (2020)

7. B. A. Kheifets, V. Yu. Chernova Economic issues, 4, 74-89, (2019)

8. T. A. Yashkova, I. B. Kabytkina Actual problems of the development of the Russian state and law: a collective monograph. (Moscow: Maks PRESS, 2018)

9. S. G. Kiselev, T. A. Yashkova, R. A. Yavchunovskaya, I. B. Kabytkina, D. F. Gurinovich, A. B. Opokin International Journal of Management and Business Research. 9(4), 198-203 (2019). 